\title{
Role of Technological Dimensions of Green Supply Chain Management Practices on Firm Performance
}

\begin{abstract}
Purpose: The research study aims to investigate green supply chain management (GSCM) elements as part of a complete system. It aims to understand the special properties of GSCM system under the moderating effects of product complexity and purchasing structure.

Methodology: A thorough literature review led to the building of the conceptual framework. Six constructs were identified using systems theory. These constructs include green supply chain technological dimensions (particularly, Artificial Intelligence (AI) based), green supply chain strategy, green supply chain process, product complexity, purchasing structure, and firm performance. The instrument was scientifically developed for gathering survey responses using Dillman's (2007) complete design test methods. The conceptual model was eventually tested based on survey data collected from 250 automotive component and allied manufacturers in the emerging economy of South Africa.
\end{abstract}

Findings: The results indicate that GSCM technological dimensions (AI-based) positively influence GSCM strategy. Further, GSCM strategy was found to positively influence GSCM process. The GSCM processes have significant effects on environmental performance, social performance and financial performance. The product complexity has a significant moderation effect on the paths GSCM strategy and GSCM process.

Originality: The findings from multivariate data analysis provide a better understanding of GSCM system dynamics and are helpful to key decision makers. This unique model has elevated GSCM theory to a new level. There are limited studies available in the existing GSCM literature using systems theory. This study will offer an advanced/comprehensive understanding to readers in this relatively new concept.

Keywords: Green Supply Chain Management; Artificial Intelligence; Firm Performance; Systems Theory

\section{Introduction}

With an increasing number of global disasters and ecologists predicting the rise of sea levels due to melting ice caps, fear has increased in the human population over the last 20 years (Van Aalst, 2006; Huserbråten et al., 2019). Worldwide warming is the consequence of an ecological disparity created by the overuse of natural resources, improper disposal of 
plastics and rubber, high levels of waste generation, and overall degradation of the environment (Pimentel and Pimentel, 2006; Peñuelas et al., 2012). Business dynamics and business development have been found to be the main drivers of environmental transformation (Omer, 2008). Business actions are vastly changing the natural environment and can endanger the earth. Traditional business models did not take environmental thresholds into consideration and increasingly consumed natural resources without applying the principles of recycling, reusing, and remanufacturing (Song et al., 2015; Dubey et al., 2016, 2019; El-Kassar and Singh, 2019). In recent years, a heightened awareness of the environment has increased the pressure on local and national government bodies to create environmental protection policies and strictly enforce them to prevent further environmental degradation (Mani et al., 2016; Song and Wang, 2018). This is the one of the main reasons for evolution in green supply chain management (GSCM) practices (Li and Zhang, 2018). Firms have started integrating GSCM with other business management functions such as procurement, production, maintenance, and logistics (Srivastava, 2007; Song et al., 2018; Tseng et al., 2018). The concept of GSCM has gained popularity through knowledge sharing in various international conferences and rising empirical research is indicating the important link between GSCM program and performance of companies (Vanalle et al., 2017). GSCM is a catalyst for bringing about the business transformations needed for a more equitable and green economy. The research team has considered Handfield's definition, as it provides the clearest definition of the subject. Handfield et al. (2005) define GSCM as a system that combines strategic, tactical and operational practices for monitoring, measuring and reporting GSCM information to a firm's stakeholders.

GSCM is a complex system with forward and reverse material flows involving product recalls, remanufacturing and safe disposal procedures (Hallam and Contreras, 2016). Vertical integration involving collaboration with suppliers and customers aids in effective flow in the closed loop. Therefore, GSCM can be used as a vital tool in the context of circular economy for the sustainable use of resources (Mangla et al., 2018).

Such complex processes call for the development of a special theory to study its behavior. GSCM can be viewed as a system with subsystems and processes aiming to minimize environmental impact. Koh et al. (2012) suggest that the entire GSCM system must understand the co-benefits, but simultaneously disregard suboptimal solutions. Systems thinking, and systems theory allow practitioners to study the complete system rather than individual elements separately. It enables the investigation of all element linkages in the 
system and manages the system functioning in a more comprehensive fashion (Checkland, 1997; Koh et al., 2016).

In modern business the competition is mainly between supply chains of various firms (Gunasekaran et al., 2004). Information sharing and collaborative effect are the key factors impacting supply chain performance (Wu et al., 2014; Archer et al., 2016). Supplier innovativeness influences sharing of information and supply chain quickness (Kim and Chai, 2017; Oliva et al., 2019). Information sharing and supply chain connectivity resources positively influence capability to improve level of visibility in auto component manufacturing firms; and it further enhances supply chain agility, adaptability and alignment (Dubey et al., 2018b). Therefore, managing information to enable logistics flow is a critical success factor in this volatile business environment. Environmental management information sharing with suppliers, customers and supply chain partners can bring cost and environmental performance benefits (Jabbour, 2015; Zhang and Yang, 2016). Information system plays an important role in activating and converting green processes and practices in firms, and enhancing environmental and economic performance (Khan et al., 2016). In this era of Industry 4.0 various choices of basic and advanced information and communication technologies are available to firms for better decision making using real time information (Rezaei et al., 2017; Singh and El-Kassar, 2019). The application of instrumentation and intelligent technologies such as ERP, PLC, HMI, SCADA, RFID tags and sensors, Global positioning systems, global information systems, vehicular ad-hoc networks, smart mobile devices, shelf moving robots, automated guided vehicles, and warehouse management systems have fast tracked the supply chain operations and also improved information sharing across the verticals of supply chain (Themistocleous et al., 2005; Piotrowicz and Cuthbertson, 2009; Bag et al., 2020a). Therefore, basics of instrumentation such as sensors and probes, data loggers, process controllers, panel meters, chart recorders, handheld devices, signal conditioners, balances and scales, and calibration equipment are playing a big role in data collection and further enhancing supply chain competitiveness. Technological integration across the verticals in the supply chain enhances remanufacturing and green manufacturing capabilities in an organization (Pan et al., 2017; Gupta et al., 2019).

Artificial intelligence systems such as agent-based systems, genetic algorithms and expert systems are gaining popularity in the field of supply chain management (Min, 2010). AI systems can be used in planning, controlling and managing systems in a systematic manner (Wang et al., 2011). 
GSCM is a complex process and without proper planning and control the entire system can fail to deliver desired results. Data collection from every process step is necessary for extracting key information. Intelligent technologies can be used to collect data and further AI can be applied to plan and control supply chain systems (Bottani et al., 2019) for sustainability. However, literature lacks detailed integration of AI systems in the GSCM process and can be considered as a gap in the existing literature. Further investigation is necessary to explore the extent of AI application in information processing in automotive and allied manufacturing firms practicing GSCM.

There are various GSCM dimensions that must still be explored to extend GSCM theory. Purchasing structure is vital in the success of new and innovative projects (Ates et al., 2018). Key factors that can influence the purchasing structure include the importance of the purchase, the time constraints, the purchasing situation, and the business model of the organization (Lau et al., 1999). Purchasing structures have GSCM-specific implications, and therefore, it is important to align the purchasing structure with GSCM strategy (Miemczyk et al., 2012; Epstein and Buhovac, 2014).

Paulraj (2011) previously tested the moderating effect of strategic purchasing between enviropreneurship and sustainable supply chain management and found it to be supported.

Eckstein et al. (2015) argued that product complexity positively moderates the relationship between supply chain adaptableness and operational output and influences the timing and introduction of new products in the market because it involves complex decisions and various skill sets (Caniato and Größler, 2015; Busogi et al., 2017; Keivanpour and Ait Kadi, 2017; Tang et al., 2017). Product complexities include the sophistication of products, which involve technological complexity; formal procedures; innovative capability of suppliers to produce the components; and availability of production knowledge. Product complexities may increase the cost of final green products and take more time in the development stage (Hartmann, 2002; Kogg and Mont, 2012). Thus, it is essential to adopt a suitable GSCM strategy based on the nature of product complexities and further select the GSCM process for meeting sustainability goals.

Therefore, it would be illuminating to observe the moderating role of purchasing structure and product complexity on the GSCM system. Previous studies have not studied the GSCM as a whole system, which is rooted in a complex set of functional relationships. Hence, the present study aspires to fill the research gaps by building and extending the GSCM knowledge base using the popular systems theory. 
The research objectives for this study are to (i) identify the GSCM system constructs through a review of literature; (ii) develop a conceptual framework based on GSCM system; (iii) test whether product complexity has a moderating effect on GSCM strategy's impact on the GSCM process; and (iv) test whether purchasing strategy has a moderating effect on GSCM strategy's impact on the GSCM process.

The remaining document is organized as follows: Next section present review of organizational theories applied to GSCM. Section 3 covers the research framework and hypotheses development. The research design used in the current study is presented in section 4. Analysis of data and findings are presented in section 5 followed by the discussion. Final section presents the conclusion and future research directions.

\section{Theoretical Background}

This segment presents the relevant studies on GSCM, mainly focusing on organizational theories applied in GSCM.

\subsection{GSCM}

A forward supply chain will transform into a closed loop system based on the environmental goals. The GSCM system redesign, considering environmental objectives, will lead to the use of waste material contributing to the next manufacturing process and producing a final item that effectively supports the remanufacturing principles (Marshall et al., 2014).

The changeover from a forward supply chain to a closed loop supply chain in this circular economy has changed all the dimensions and scope of traditional supply chains. However, sustaining the changes is not a simple task and understanding critical enablers is crucial for organizations. There are other factors which organizations must consider while practicing environmental management. ISO 14001 can help firms to achieve the sustainability goals and implementation of GSCM (Jabbour, 2010) as it indicates requirements of a valuable environmental management system.

Literature indicates that organizations must focus on development of human resources for effective environmental management in organizations (Jabbour et al., 2013; Jabbour and de Sousa Jabbour, 2016). Human factors are playing a crucial role in green product development and improving firm performance in developing countries (Jabbour et al., 2015) and help in transforming to a circular economy (Jabbour et al., 2019).

A circular economy is another concept that has recently attracted the attention of the research community (Chen et al., 2018; Kumar et al., 2019). In a circular economy, the 
significance of items is retained for a longer time frame, and material can be re-used and remanufactured (Bag et al., 2019). Therefore, resources stay within the system and can be utilized again for future value generation (Dubey et al., 2018a; Lyu et al., 2019).

Product design plays a key role at the tactical level in green supply chains. Product complexity calls for various technological applications which may influence the conversion time, wastage, product life cycle, and customer satisfaction (Larsen et al., 2018).

Literature also indicates that that competitiveness is the top critical enabler in achieving sustainability. Managing suppliers plays a decisive role in influencing the GSCM initiatives (Luthra et al., 2015). Green design and purchasing are found to be critical enablers in driving GSCM projects (Luthra et al., 2018).

Apart from highlighting the role of critical factors, Luthra et al. (2018) also discussed various research gaps. One of them is the need to investigate GSCM from a systems perspective rather than examining it through an individual stakeholder lens. Today's dynamic business environment has made supply chains more complex, exposing them to multiple risks. Therefore, researchers must look at such complex chains and analyze the effects under the interaction of various GSCM elements. This may help to answer the previous research calls and further extend GSCM theory.

\subsection{Review of Organization theories applied in GSCM}

Here, we discuss the various organizational theories applied to GSCM. For instance, Jänicke and Jacob (2006) reasoned on Ecological modernization theory and environmental policies. According to Sarkis et al. (2011), organization theories are useful in explaining behavior of firms due to their design and structure. Organization theory can also be expanded to study the supply chain relationships that connect firms (Sarkis et al., 2011).

Sarkis et al. (2011) discussed nine theories and presented a tabulated format detailing the existing GSCM research works and application of organization theories. Jayaram and Avittathur (2015) presented ten relevant theories for application in GSCM. The study by Spina et al. (2016) assessed the role of External Grand theories in purchasing and supply management (PSM). They found that the most commonly used theories that are applied in PSM are Resource Based View, Knowledge Based theory, Transaction Cost Economics, Game theory, Contingency theory, Social Exchange theory, Agency theory, Resource Dependency theory, Information Processing theory, Institution theory, Dynamic Capabilities theory and Network theory.

The above studies are considered pivotal in expanding GSCM theory. However, none discussed the application of systems theory in GSCM until a recently published paper by 
Dubey et al. (2017).

While searching previous literature we found that Holt and Ghobadian (2009) and Koh et al. (2012) authored two studies that attempted to build systems theory into the existing GSCM model. Ultimately, it seems that the contribution to systems theory in the field of GSCM has been under-researched.

While conducting a review of existing GSCM theories, Dubey et al. (2017) discussed thirteen theories. The paper written by Dubey et al. (2017) combined the knowledge-based theory and the systems theory to propose a GSCM theoretical framework. They have also indicated that past research focuses on either the macro or micro level theoretical application of GSCM.

From review of formative papers, it is evident that no studies have looked at GSCM as a complete system and examined the effect under the moderating role of purchasing structure and product complexity.

\section{Research framework and hypothesis development}

This section provides the basis of developing the theoretical structure and research plan for testing purpose.

Some of the significant papers on GSCM and the GSCM framework, which show key directions, are used to identify six constructs critical for GSCM system success in the automobile and allied manufacturing sectors. The constructs and their measures are presented in Table 4.

The unique conceptual framework proposed by Dubey et al. (2017) is very interesting and has been extended for the purpose of empirical research in the current study (Figure 1). However, systems theory is used here to develop the conceptual model. The inception of systems theory dates back to the eighteenth century. Systems theory is an interdisciplinary theory that considers complex mechanisms to produce a framework by which a researcher can examine any group of units that work together to generate some output (Boulding, 1956; Johnson et al., 1964; Kast and Rosenzweig, 1972; Patten, 1978; Checkland, 1994). Here, the research team views GSCM elements as a web of relationships that form an entire system. It will then become easier for the research team to define the GSCM system as a bundle of relationships acting as a system unit. In the whole system, relationships between GSCM and its elements are documented as the primary source of complexity.

In the current model, inputs are made up of the physical flow of raw material and information, which is fed into the GSCM system. The elements in the system are GSCM 
Technological Dimensions (GSCM HD), GSCM Strategy (GSCMS), GSCM Process (GSCM PR), Product Complexity (PC), Purchasing Structure (PS), and Firm Performance (FIP). The outputs of the GSCM system are final products and information, which ultimately influence the planet. System dynamics have been used to estimate the dynamic behavior of complex GSCM systems.

The limitations of the previous GSCM models are that most of them have been investigated in isolation. However, the whole model as a single system has some special properties that cannot be captured in isolation. We intend to capture the special properties through our systems-based model.

\section{[Figure 1 in here]}

GSCM Technological Dimensions (GSCM HD) include AI based technologies such as agent-based systems, genetic algorithm and expert systems that influence GSCM system. A green supply chain consists of more than hundreds of processes considering from business process level 0 to level 4 . Every process is interlinked and dependent on each other for executing a task. GSCM system is very dynamic and complex system. It involves multiple criteria which call for expert decision making. Industry 4.0 technologies such as IoT can be used to collect data from various points and further AI can be applied for planning and control of GSCM systems. AI-based technological enablement can be a valuable tool to connect green customers, green suppliers and green supply chain collaborators through exchange of information across the verticals of supply chain. Agent based systems can be extremely useful in relationship building with green customers, green suppliers and business partners. Agent based systems add great value in supply chain coordination and collaborative demand planning in green supply chains. Agent based systems can solve many GSCM problems that traditional analytical models fail. Genetic algorithms can be used in green logistics management such as vehicle routing and scheduling, container loading, and material handling problems in GSCM. AI-based technological enablement thus influences selection of appropriate strategies and action plans (Min, 2010; Dwivedi et al., 2019).

We therefore hypothesize:

H1. GSCM Technological Dimensions (GSCM HD) positively influence GSCM Strategy (GSCMS).

The four types of GSCM strategies are risk-based strategy, efficiency strategy, innovation strategy and closed loop strategy. Therefore, GSCM process (GSCM PR) is determined based on the GSCM strategy (GSCMS) adopted by the firm (Sarkis, 2012; 
Jabbour et al., 2017; Singh et al., 2019a; Singh et al., 2020).

We therefore hypothesize:

H2. GSCM Strategy (GSCMS) positively influences GSCM Process (GSCMPR).

GSCM process (GSCMP) involves the capacity and capability of the firm to execute any job as per the GSCM strategy (GSCMS) adopted by the firm. If the GSCMS is not appropriate in that particular situation, the GSCMP will not function properly and will not produce desired output. If there is a GSCMS and GSCM PR misfit, there is a high chance of negative effect on performance. Firms normally use a mix of multiple GSCMS to enhance GSCMP. The ultimate aim, however, is to improve EP, SP and FP. Firms focus highly on adopting the correct GSCM PR through collaborative relationships, building specialized knowledge and leveraging on advanced technology to enhance FP (Hervani et al., 2005; Chen et al., 2012; Ware et al., 2014; Patnaik et al., 2018; Singh et al., 2019b).

We therefore hypothesize:

H3. GSCM Process (GSCM PR) positively influences Firm Performance (FIP).

H3a. GSCM Process (GSCM PR) positively influences Environmental Performance (EP)

H3b. GSCM Process (GSCM PR) positively influences Social Performance (SP)

H3c. GSCM Process (GSCM PR) positively influences Financial Performance (FP)

Product Complexity (PC) involves a firm's product portfolio, product design, component choices, complexity decisions, degree of customization, choice of system architecture, and engineering/management skills necessary to produce the items. Therefore, PC has the ability to amplify or reverse the causal relationship between GSCM Strategy (GSCMS) and GSCM Process (GSCM PR) (Eckstein et al., 2015).

We therefore hypothesize:

H4. Product Complexity (PC) has a moderating effect on GSCM Strategy (GSCMS) impact on GSCM Process (GSCMP).

Purchasing Structure (PS) can be either centralization, formalization, cross-functional or a mix of the three. PS follows GSCMS and in the case of misfit, it may not generate the required outcome or may even create a negative outcome. Therefore, PS has the ability to amplify or reverse the causal relationship between GSCM Strategy (GSCMS) and GSCM Process (GSCMP) (Ates et al., 2018).

We therefore hypothesize:

H5. Purchasing Structure (PS) has a moderating effect on GSCM Strategy (GSCMS) impact 
on GSCM Process (GSCMP).

\section{Research Design}

This part presents the methodology used for statistical validation of the conceptual model.

\subsection{Research Instrument}

GSCM Technological Dimensions, GSCM Strategy, and GSCM Process are the three predictors; two moderating variables are Product Complexity and Purchasing Structure; and the final outcome variable (Firm Performance) (Table 4).

\subsection{Sample and Survey Description}

The study is carried out in the background of the South African economy. Recently, this country has adopted the Reconstruction and Development Programme (RDP) with the aim to eliminate earlier ecological malpractices which resulted in distress among people. RDP program has a mission to develop sustainability by referring to guidelines pointed out in the Agenda 21 of the UN Program for worldwide sustainable improvement (Coetzee and Bean, 2016).

The target population is the manufacturing sector with special emphasis on the automobile industry. There are two major motives for studying this industry. First, this industry is the backbone of the country's economic development, and it has recently adopted a range of sustainable initiatives. Second, limited studies exist in the context of sustainability practices in the South African automobile and allied manufacturing sector.

The research team approached supply chain managers in automobile manufacturing and automotive components manufacturing firms to complete an online based survey. For our sampling strategy, we used the popular convenience sampling plan. The email list was compiled from the database of The National Association of Automotive Component and Allied Manufacturers.

The sampling formula considered here is presented below.

$\mathrm{n}=\mathrm{N} /\left[1+\mathrm{N}(\mathrm{e})^{2}\right]$ Equation 1

Where;

$\mathrm{n}=$ sample size

$\mathrm{N}=$ Total population 
$\mathrm{e}=$ Error

The total population is around 1703 firms and sample size considered is 314 (Singh and Masuku, 2014, pp.11); 5\% as margin of error; confidence level is 95\% and response distribution considered is $50 \%$.

Initially, the authors conducted a pilot survey considering fifty responses from industry experts before approaching the final survey. The pretesting was beneficial for altering the questionnaire by changing the words of some questions for clearness. Authors also dropped four questions that were similar in meaning. This was done to avoid any multicollinearity problems at a later stage. A Likert scale (five-point basis) is used to collect the data, where 1 means "strongly disagree"; 2 means "agree"; 3 means "neutral"; 4 means "agree" and 5 means "strongly agree".

Survey researchers normally face many challenges when conducting data collection. To make this process easy, the authors approached only employees designated as Assistant Manager and above for obtaining data. Moreover, the authors made a clear statement on top of the survey instrument that stated that the survey would be used solely for writing an academic paper and that the identity of the survey respondents would remain fully confidential.

The authors initially emailed the questionnaire to a sample size of 314 (automobile manufacturing and automotive component manufacturing) firms. After three weeks, another email reminder was sent to survey participants who initially did not respond to the first email. Telephonic follow-ups was done to ensure that firms understood the importance of the survey. Through such requests, authors received 250 completed questionnaires back. The authors received a response rate of 79.60 percent, which is considered good in social science research. The demographic profile of respondents is presented in Table 1.

[Table 1 in here]

\subsection{Common method bias}

The research team has put additional efforts to reduce common method bias (CMB). Proper care was taken during design of survey questions. The questionnaire started with a note that the research study is intended for academic use and the data will not be used for any business-related work. The questionnaire was also aimed for employees involved in managerial work. Finally, the questionnaire was designed in such a manner so as to reduce the effect of item priming. Post survey the data was sorted and prepared to check presence of any $\mathrm{CMB}$. 
Harman's single factor test result indicates that the first factor adds $36.75 \%$ of variance which is less than $50 \%$ and it can be concluded that $\mathrm{CMB}$ is not influencing the data.

\subsection{Non-response bias}

Scientific research approach was adopted to evade non-response bias. Research team used correct data base to select the email ids of target respondents. The response rate of $62.5 \%$ received after two rounds of follow-ups during survey is satisfactory (Shannon, 1948).

Further both the waves was compared using t-test. The authors considered the cut-off value of 0.05 for alpha and achieved a p-value that is higher than 0.05 , which suggests no existence of non-response bias.

\subsection{Model fit and quality indices}

The model fit and quality indices such as APC, ARS, AARS, AVIF, and AFVIF are calculated and found well within the limits.

Average path coefficient $(\mathrm{APC})=0.394, \mathrm{P}<0.001$

Average R-squared $(\mathrm{ARS})=0.395, \mathrm{P}<0.001$

Average adjusted R-squared (AARS) $=0.392, \mathrm{P}<0.001$

Average block VIF $(\mathrm{AVIF})=3.699$, acceptable if $<=5$, ideally $<=3.3$

Average full collinearity VIF $(\mathrm{AFVIF})=4.597$, acceptable if $<=5$, ideally $<=3.3$

\subsection{Causality Assessment}

The following indices were calculated to check for any causality in data and all were found to be within the acceptable limits. This indicates the model as having a good fit.

Tenenhaus GoF $(\mathrm{GoF})=0.488$, small $>=0.1$, medium $>=0.25$, large $>=0.36$

Sympson's paradox ratio $(\mathrm{SPR})=1.000$, acceptable if $>=0.7$, ideally $=1$

$\mathrm{R}$-squared contribution ratio $(\mathrm{RSCR})=1.000$, acceptable if $>=0.9$, ideally $=1$

Statistical suppression ratio $(\mathrm{SSR})=1.000$, acceptable if $>=0.7$

Nonlinear bivariate causality direction ratio $(\mathrm{NLBCDR})=0.938$, acceptable if $>=0.7$

\section{Data Analysis and Findings}

Here, the structural equation modeling technique using WarpPLS Version 6.0 was employed for statistical validation of the conceptual model. Research team attempted to gain insights from the PLS results (Ringle and Sarstedt, 2016).

Combined loadings and cross loadings were checked, and all values were found above 
0.50 and acceptable for our research. Discriminant validity was checked, and the results passed the test (Table 5). The Latent variable coefficients were calculated and presented in Table 2. Both Cronbach's alpha and Composite reliability are found to be above 0.60 , and therefore, constructs considered in the current study are reliable (Nunnally and Bernstein, 1994; Kock, 2014).

\section{[Table 2 in here]}

The model obtained after hypotheses testing is shown in Figure 2. It shows all the direct and indirect links along with beta values and $\mathrm{p}$ values.

[Figure 2 in here]

The decision of accepting or not accepting a research hypothesis is taken based on checking of each link from tested model with its $\mathrm{p}$ value. In case the $\mathrm{p}$ value is higher than 0.05 then the research hypothesis is not accepted and vice-versa (Table 3 ).

No significant effect of control variables such as firm age and firm size is found.

[Table 3 in here]

\section{Discussion}

The consideration of environmental aspects while designing strategic supply chain processes are valuable to the organization and stakeholders (Feng et al., 2018; Narwaria, 2019). Supply chain management, when looked upon from an environmental context, delivers a combined term called 'Green Supply Chain Management' (Suryanto et al., 2018). GSCM denotes the core involvement of activities, which can result in the conservation of the environment at large (Zhu et al., 2017). Broadly, GSCM is comprised of elements that pursue environmental sustainability i.e. green purchasing, green manufacturing, green distribution, green purchasing, green consuming, and recycling of resources. The existing scenario of GSCM technologies clearly explains the availability of numerous possibilities of growth and development (Saberi et al., 2018). The GSCM has evolved over the past few years (Xu et al., 2017; Saberi et al., 2019), but the assimilation of information technology and GSCM has barely received importance (Namagembe et al., 2019; Yeniyurt et al., 2019). The involvement of information technology and digital tools are complicated yet extremely useful processes to handle environmental uncertainties, which in turn initiates the timely fulfillment of customer needs and expectations (Anthony et al., 2018; Dubey et al., 2019; Lee and Chen, 2019; Martinho et al., 2019). Previous researchers (Singh and Teng, 2016) claim that information technologies are an indispensable source to aid in the implementation of GSCM practices. A technologically oriented GSCM significantly influences almost every department 
(operations, finance, human resources, sales and marketing) of every organization (Slotnick and Sobel, 2019). The incorporation of GSCM enables organizations to attain a respectable societal reputation and goodwill, but it cannot be implemented without taking into consideration the digitalization of GSCM practices (Stadtler 2015; Pettit et al., 2019). Gaining a competitive edge is all about winning the customers' heart by delivering all of the possible services that matchwith the latest trends. The technologically oriented GSCM opens new avenues of knowledge and skills, which seconds the elite range of products and services made for the customers in respect to the majority of services (Mishra et al., 2018; Ali and Haseeb 2019). Keeping the above perspective into deep consideration, the present paper is a modest attempt to explore the importance of technological involvement (specifically AI) with GSCM. The findings of our study show that GSCM's technological dimensions have a positive relationship with the GSCM strategy. The Application of Artificial intelligence (AI) in GSCM is something companies have only started including recently. Due to various operational challenges and complexities the AI application is currently at a superficial level and restricted to the use of agent based systems for green demand planning and forecasting, negotiation with green suppliers, green customer relationship management, order picking in green warehouse management, and integration and coordination in green supply chains. Companies are also using Genetic algorithm based programmes for green supply chain network design, and using expert systems for green logistics strategy formulation, green inventory planning and management, green decision making and green supplier selection.

The fourth industrial revolution has promoted technological innovations and facilitated automation in business processes (Bag et al., 2020a,b). These findings are supported by the study of Dwivedi et al. (2019) which suggested that AI has the potential to replace manual tasks and activities within business processes with the recent breakthroughs in algorithmic machine learning and autonomous decision making.

Traditional supply chain processes have been disrupted by the onset of these AI based technology applications. AI technological enablement will guide the organization to adopt the right GSCM strategy, such as a green supply chain network design including green supplier selection, managing green warehousing and green logistics.

In recent times manufacturing companies have received environmental pressures from customers and the government ( $\mathrm{Li}$ et al., 2019). The main purpose forcreating such environmental pressures is to effectively manage the end of life products to help reduce the impact on the environment (Chen and Akmalul'Ulya, 2019). Our findings show that the GSCM strategy positively influences the GSCM process. The right strategy will naturally 
drive the correct GSCM process. Finally our study shows that the GSCM process positively influences environmental performance, social performance and financial performance. These findings corroborate with the findings of Waltho et al. (2018).

Cousins et al. (2019) also suggested that GSCM practices are associated with a high level of environmental and financial performance. However, findings from our study highlight that GSCM processes are fundamentally important to attainingthe desired sustainable outcome.

The uniqueness of our study comes fromthe pathways that are tested and validated in context to an emerging economy like South Africa.

\subsection{Implications for theory}

The study aims to understand how the GSCM system will function under acomplex circular environment and what effect the GSCM system will have on environmental, financial and social performances. Additionally, the research team studied the behavior of GSCM strategy on the GSCM process under the moderation effect of product complexity and purchasing structure. The findings of the research study provided answers to all of the research questions and extended the GSCM literature. Systems thinking, and systems theory allowed the research team to study the complete GSCM system, rather than GSCM's individual elements separately. It enabled the investigation of all GCSM element linkages in the system to help further manage the system so that it was functioning in a more comprehensive fashion. The present study fills the existing research gaps by building and extending the GSCM knowledge base using the popular systems theory. GSCM elements act as a web of relationships that form an entire system. It became easier for the research team to define the GSCM system as a bundle of relationships acting as one system unit. In the whole system, relationships between GSCM and its elements are documented as the primary source of complexity. In the current model, inputs consist of the physical flow of raw material and information, which is fed into the GSCM system. The elements in the system are GSCM Technological Dimensions, GSCM Strategy, GSCM Process, Product Complexity, Purchasing Structure, and Firm Performance. The output of the GSCM system consists of final products and information, which ultimately influences not only the stakeholders but also our planet. System dynamics explains the dynamic behavior of complex GSCM systems and further extends the knowledge base thus addressing the call of previous researchers.

\subsection{Practical implications}

The key take away points for managers are as below.

Aligning with local sustainability goals: The South African government has adopted the RDP program, aligning with sustainability goals for improvement of the people and the economy. 
The findings offer practical solutions to complex problems which may help overcome the challenges faced by businesses in implementing green programs. Managers need to be aware of these critical AI based technological dimensions, which we have discussed in our study where we carefully frame green programs.

Focus on green capability development: The findings provide a road map for managers to implement and control the GSCM system as a whole. They need to focus on cost management, while also developing long-term relationships with suppliers and customers. This will allow the firm to enhance its green research and development capabilities and further offer innovative green products and services to the market.

Develop smart GSCM strategy: GSCM strategy ultimately determines the GSCM process. GSCM strategy can include the development and use of green suppliers; collaboration with customers for green product developments; use of lean tools such as 5S; and optimization of the processes to minimize wastage and losses (Panahifar et al., 2018). Thus, environmental goals will automatically align with the operational process. Smart GSCM strategy can help with reduction in usage of energy and resources that can drive economic growth (Song et al., 2011; Song et al., 2012).

GSCM process determines the final output of the GSCM system: Managers must closely focus on the nature and quality of the inputs to avoid any negative environmental, financial and social consequences. Normally, the policy and standard operating procedures (SOP) guide the process, thus companies must strictly follow SOPs to meet their sustainable goals.

Focus in process automation using AI based technologies: Such advanced technologies can help firms overcome the GSCM related challenges in a circular economy by providing near real time information for timely and quality decision making which in turn gives better knowledge management of the GSCM system. This will enhance the agility of the supply chain network (Giannakis and Louis, 2016). There are several operational challenges faced by firms in this dynamic business environment, but these challenges mainly effect a developing economy like South Africa, where cost is the main focus. However, adoption of an AI driven GSCM system can provide superior benefits directly or indirectly that are much more valuable when compared to the costs incurred during the initial investment phase for designing and implementing such advanced technologies.

Managers must not forget that product complexity affects the strength of the relation between GSCM strategy and the GSCM process: GSCM strategy will change based on the nature of the product/components under manufacturing. Managers must set benchmarks and continuously improve their firm's green capabilities to ease in the disassembly and 
remanufacturing of products.

Focus on environmental management systems and information sharing: Developing a complete closed loop GSCM system will improve information sharing and supply chain connectivity; and will further enhance supply chain agility, adaptability and alignment. Managers need to focus on environmental management systems for information sharing with suppliers, customers and supply chain partners that can bring cost down and environmental performance benefits up.

\section{Conclusion}

The broader impact from this study is summarized as follows:

Green supply chain management (GSCM) is a popular choice of management researchers due to its evolving nature. Previous researchers have used mainly the Institutional theory and RBV theory to study GSCM dimensions. However, management scholars have ignored many important dimensions in that process until recently when an article by Dubey et al. (2017) discussed GSCM from a Systems theory perspective, capturing many important GSCM dimensions neglected by earlier researchers.

This study extends the conceptual framework recommended by Dubey et al. (2017), looks into the green supply chain management (GSCM), and associate elements as a web or whole system in order to understand its special properties. GSCM is a system where inputs such as raw material, fuel, and energy, are fed into the system, are further processed based on the selected GSCM strategy and the output comes out in the form of products and byproducts. Every GSCM dimension is functionally linked with one another, and they flow from one node to the other to process the information and physical material. There may be multiple iterations to complete the process, and supply chain managers need to be aware of these processes. The conceptual model developed using systems theory is eventually tested based on the study information collected from 250 automotive and allied production-based firms. These sectors are dynamic and face multiple challenges, and hence were selected for this study. The authors checked the construct reliability and other psychometric properties using confirmatory factor analysis. Further, SEM was applied to statistically validate the conceptual model. The findings contribute uniquely to the existing theory. Out of five research hypotheses, only one hypothesis was rejected.

GSCM Technological Dimensions (AI based) positively influence GSCM strategy. GSCM strategy is found to have a significant relationship with the GSCM process. GSCM process is also found to positively influence firm performance (environmental, social and 
financial). However, GSCM process has a stronger influence on social performance than it has on environmental and financial performance.

In our study, we assumed two moderating relationships. However, based on the evidence, only one moderating effect is found to exist. The influence of product complexity on GSCM Strategy (GSCMS) impact on GSCM Process (GSCM PR) is found to be supported. However, the moderating role of Purchasing Structure (PS) on GSCM Strategy (GSCMS) impact on GSCM Process (GSCM PR) is not supported. If we look at the GSCM literature, we can see the findings corroborate with past studies such as Zhu et al. (2005).

Previous studies such as Koh et al. (2012) have adopted the systems theory to analyze the interrelationships between elements in a supply chain and identified a newer kind of impact, which was named the cross-tier ripple effect stimulated by WEEE and RoHS directives. The study provides a new approach to plan and control green supply chain management programs and aims to bridge the gaps between concepts of GSCM functionality and changes in levels of product complexity.

\subsection{Limitations and directions of future research}

We have taken care to avoid any bias. Hwever, like any research study, this study suffers from certain limitations.

Firstly, convenient sampling technique and cross-sectional data were used for data collection, analysis and statistical validation. Wethink is a limitation for the study. Future studies can be conducted using longitudinal data gathered using a random sampling approach and then can be compared with the current findings.

Secondly, in the current study, only AI-based technological dimension is considered; however, in future research other technological dimensions should be considered.

Future research studies can include checking the moderating effect of green intellectual capital on how the GSCM process impacts firm performance.

It would also be appealing to see how the moderating effect of resources and capabilities on GSCM process impacts firm performance. Fantazy and Tipu (2019) indicated that a culture of competitiveness and knowledge development has a positive relationship with green supply chain management and overall company performance. Our study did not consider any of these resources and capabilities to estimate the final outcome, thusthey can be considered in future research studies. Similarly, Kumar et al. (2019) confirmed that human resource related soft dimensions influence the GSCM process. Another study by Singh et al. (2019c) suggested that environmental ethics influences environmental training and environmental performance. Future research studies can consider both hard and soft GSCM 
dimensions in the theoretical model to check the interplay between them and their joint impact on the final outcome (organization performance).

Further, Rahman et al. (2019) identified enablers and barriers of flexible green supply chain management. Future research can check the moderating effect of control orientation and flexible orientation on GSCM process' impact on firm performance, which may provide some rich insights.

Researchers may also think of extending/integrating GSCM theory with humanitarian logistics.

Finally, it would also be interesting to study the impact of predictive analysis and data mining in matching green product supply and demand.

\section{References}

Ali, A. and Haseeb, M. (2019), "Radio frequency identification (RFID) technology as a strategic tool towards higher performance of supply chain operations in textile and apparel industry of Malaysia”, Uncertain Supply Chain Management, Vol. 7 No. 2, pp. 215-226.

Anthony Jr, B., Abdul Majid, M. and Romli, A. (2018), “A collaborative agent based green IS practice assessment tool for environmental sustainability attainment in enterprise data centers", Journal of Enterprise Information Management, Vol. 31 No. 5, pp. 771-795.

Archer, N. P., Hong, P. and Jeong, J. (2006), "Supply chain management practices of SMEs: from a business growth perspective", Journal of Enterprise Information Management, Vol. 19 No. 3, pp. 292-302.

Ateş, M. A., van Raaij, E. M., and Wynstra, F., (2018), “The impact of purchasing strategystructure (mis) fit on purchasing cost and innovation performance", Journal of Purchasing and Supply Management, Vol. 24 No. 1, pp. 68-82.

Bag, S., Gupta, S. and Foropon, C., (2019), "Examining the role of dynamic remanufacturing capability on supply chain resilience in circular economy", Management Decision, Vol. 57 No. 4, pp. 863-885.

Bag, S., Wood, L. C., Xu, L., Dhamija, P. and Kayikci, Y. (2020a), "Big data analytics as an operational excellence approach to enhance sustainable supply chain performance", Resources, Conservation and Recycling, Vol. 153 No.(February), 104559. 
Bag, S., Wood, L. C., Mangla, S. K. and Luthra, S. (2020b), "Procurement 4.0 and its implications on business process performance in a circular economy", Resources, Conservation and Recycling, Vol. 152 No.(January), 104502.

Bottani, E., Centobelli, P., Gallo, M., Kaviani, M. A., Jain, V. and Murino, T. (2019), "Modelling wholesale distribution operations: an artificial intelligence framework", Industrial Management \& Data Systems, Vol. 119 No. 4, pp. 698-718.

Boulding, K. E., (1956), "General systems theory-the skeleton of science”, Management Science, Vol. 2 No. 3, pp.197-208.

Busogi, M., K. Ransikarbum, Y. G. Oh, and Kim, N. (2017), "Computational modelling of manufacturing choice complexity in a mixed-model assembly line", International Journal of Production Research, Vol. 55 No. 20, pp. 1-15.

Caniato, F., and Größler, A., (2015), “The moderating effect of product complexity on new product development and supply chain management integration", Production Planning \& Control, Vol. 26 No. 16, pp. 1306-1317.

Checkland, P., (1994), "Systems theory and management thinking", American Behavioral Scientist, Vol. 38 No. 1, pp. 75-91.

Checkland, P., (1997), "Systems Thinking, Systems Practice”, John Wiley \& Sons, Ltd., Chichester.

Chen, C. K. and Akmalul'Ulya, M. (2019), "Analyses of the reward-penalty mechanism in green closed-loop supply chains with product remanufacturing", International Journal of Production Economics, Vol. 210 No. (April), pp. 211-223.

Chen, C. C., H. S. Shih, H. J. Shyur, and Wu, K. S., (2012), “A business strategy selection of green supply chain management via an analytic network process", Computers \& Mathematics with Applications, Vol. 64 No. 8, pp. 2544-2557.

Chen, J., Wu, Y., Xu, C., Song, M., and Liu, X., (2018), "Global non-fossil fuel consumption: driving factors, disparities, and trends", Management Decision, Vol. 57 No. 4, pp. 791-810

Coetzee, N, and Bean, W. L., (2016), "A green profitability framework to quantify the impact of green supply chain management in South Africa", Journal of Transport and Supply Chain Management, Vol. 10 No. 1, pp. 1-15.

Cousins, P. D., Lawson, B., Petersen, K. J. and Fugate, B. (2019), "Investigating green supply chain management practices and performance", International Journal of Operations \& Production Management. Vol. 39 No. 5, pp. 767-786. 
Dillman D., (2007), "Mail and internet surveys: the tailored design method", Wiley, New York

Dubey, R., Gunasekaran, A., and Papadopoulos, T., (2017), "Green supply chain management: theoretical framework and further research directions", Benchmarking. An International Journal, Vol. 24 No. 1, pp. 184-218.

Dubey, R., Gunasekaran, A., Childe, S.J., Papadopoulos, T., Fosso-Wamba, S., and Song, M., (2016), "Towards a theory of sustainable consumption and production: Constructs and measurement", Resources, Conservation and Recycling, Vol. 106 No. (January), pp. 78-89.

Dubey, R., Gunasekaran, A., Childe, S. J., Papadopoulos, T., and Helo, P., (2018a), "Supplier relationship management for circular economy: influence of external pressures and top management commitment”, Management Decision, Vol. 57 No. 4, pp. $767-790$

Dubey, R., Altay, N., Gunasekaran, A., Blome, C., Papadopoulos, T., and Childe, S. J. (2018b), "Supply chain agility, adaptability and alignment: empirical evidence from the Indian auto components industry", International Journal of Operations \& Production Management, Vol. 38 No. 1, pp.129-148.

Dubey, R., Gunasekaran, A., Childe, S. J., Papadopoulos, T., Luo, Z., Wamba, S. F. and Roubaud, D. (2019), "Can big data and predictive analytics improve social and environmental sustainability?", Technological Forecasting and Social Change, Vol. 144 No. (July), pp. 534-545.

Dwivedi, Y. K., Hughes, L., Ismagilova, E., Aarts, G., Coombs, C., Crick, T. and Galanos, V. (2019), “Artificial Intelligence (AI): Multidisciplinary perspectives on emerging challenges, opportunities, and agenda for research, practice and policy”, International Journal of Information Management. https://doi.org/10.1016/j.ijinfomgt.2019.08.002

Eckstein, D, Goellner, M. , Blome, C. and Henke, M., (2015), „The performance impact of supply chain agility and supply chain adaptability: the moderating effect of product complexity", International Journal of Production Research, Vol. 53 No.10, pp. 3028-3046.

El-Kassar, A. N. and Singh, S. K. (2019), "Green innovation and organizational performance: the influence of big data and the moderating role of management commitment and HR practices", Technological Forecasting and Social Change, Vol. 144 No. (July), pp. 483-498. 
Epstein, M. J. and Buhovac, A. R., (2014), "Making sustainability work: Best practices in managing and measuring corporate social, environmental, and economic impacts", Berrett-Koehler Publishers.

Fantazy, K. and Tipu, S. A. A. (2019), "Exploring the relationships of the culture of competitiveness and knowledge development to sustainable supply chain management and organizational performance", Journal of Enterprise Information Management, Vol. 32 No. 6, pp. 936-963.

Feng, M., Yu, W., Wang, X., Wong, C. Y., Xu, M. and Xiao, Z. (2018), “Green supply chain management and financial performance: The mediating roles of operational and environmental performance", Business Strategy and the Environment, Vol. 27 No. 7, pp.811-824.

Giannakis, M. and Louis, M. (2016), “A multi-agent based system with big data processing for enhanced supply chain agility", Journal of Enterprise Information Management, Vol. 29 No. 5, pp. 706-727.

Gunasekaran, A., Patel, C., and McGaughey, R. E. (2004), “A framework for supply chain performance measurement", International Journal of Production Economics, Vol. 87 No. 3, pp. 333-347.

Gupta, S., Drave, V. A., Bag, S. and Luo, Z. (2019), "Leveraging Smart Supply Chain and Information System Agility for Supply Chain Flexibility", Information Systems Frontiers, Vol. 21 No.3, pp. 547-564.

Gupta, S., Kumar, S., Singh, S. K., Foropon, C. and Chandra, C. (2018), "Role of cloud ERP on the performance of an organization: contingent resource-based view perspective", The International Journal of Logistics Management, Vol. 29 No. 2, pp. $659-675$

Hallam, C., and Contreras, C., (2016), "Integrating lean and green management”, Management Decision, Vol. 54 No. 9, No.2157-2187.

Handfield, R., Sroufe, R. and Walton, S., (2005), "Integrating environmental management and supply chain strategy", Business Strategy and the Environment, Vol. 14 No. (January/February), pp. 1-19.

Hartmann, E. (2002), "Determining the purchase situation: Cornerstone of supplier relationship management”, In B-to-B Electronic Marketplaces, pp. 7-31. Deutscher Universitätsverlag, Wiesbaden. 
Hervani, A. A., Helms, M. M. and Sarkis, J., (2005), "Performance measurement for green supply chain management”, Benchmarking: An International Journal, Vol. 12 No. 4, pp.330-353.

Holt, D. and Ghobadian, A., (2009), “An empirical study of green supply chain management practices amongst UK manufacturers", Journal of Manufacturing Technology Management, Vol. 20 No. 7, pp. 933-956.

Huserbråten, M. B. O., Eriksen, E., Gjøsæter, H. and Vikebø, F. (2019), "Polar cod in jeopardy under the retreating Arctic sea ice”, Communications Biology, Vol. 2 No. 1, pp. 1-8.

Jabbour, C. J., Mauricio, A. L. and Jabbour, A. B. L. D. S. (2017), Critical success factors and green supply chain management proactivity: shedding light on the human aspects of this relationship based on cases from the Brazilian industry, Production Planning \& Control, Vol. 28 No. (6-8), pp. 671-683.

Jabbour, C. J. C. (2015), "Environmental training and environmental management maturity of Brazilian companies with ISO14001: empirical evidence”, Journal of Cleaner Production, Vol. 96 No. (June), pp. 331-338.

Jabbour, C. J. C. (2010), "Non-linear pathways of corporate environmental management: a survey of ISO 14001-certified companies in Brazil", Journal of Cleaner Production, Vol. 18 No. 12, pp. 1222-1225.

Jabbour, C. J. C., and de Sousa Jabbour, A. B. L. (2016), "Green human resource management and green supply chain management: Linking two emerging agendas", Journal of Cleaner Production, Vol. 112, pp. 1824-1833.

Jabbour, C. J. C., Sarkis, J., de Sousa Jabbour, A. B. L., Renwick, D. W. S., Singh, S. K., Grebinevych, O., and Godinho Filho, M. (2019), "Who is in charge? A review and a research agenda on the 'human side' of the circular economy", Journal of Cleaner Production, Vol. 222 No. (Part 3, January), pp.793-801.

Jabbour, C. J. C., Jugend, D., de Sousa Jabbour, A. B. L., Gunasekaran, A. and Latan, H. (2015), "Green product development and performance of Brazilian firms: measuring the role of human and technical aspects", Journal of Cleaner Production, Vol. 87 No. (January), pp. 442-451.

Jabbour, C. J. C., Santos, F. C. A., Fonseca, S. A., and Nagano, M. S. (2013), “Green teams: understanding their roles in the environmental management of companies located in Brazil”, Journal of Cleaner Production, Vol. 46 No. (May), pp. 58-66. 
Jabbour, A.B.L.S., Frascareli, F.C.O. and Jabbour, C.J.C., (2015), “Green supply chain management and firms' performance: Understanding potential relationships and the role of green sourcing and some other green practices", Resources, Conservation and Recycling, Vol. 104 No. (Part B November), pp. 366-374.

Jänicke, M., and Jacob, K., (2006), "Environmental governance in global perspective. New Approaches to Ecological and Political Modernisation“, Berlin: Forschungsstelle für Umweltpolitik. Freie Universität Berlin.

Jayaram, J. and Avittathur, B., (2015), "Green supply chains: A perspective from an emerging economy", International Journal of Production Economics, Vol. 164 No. (June), pp. 234-244.

Johnson, R. A., Kast, F. E., and Rosenzweig, J. E., (1964), "Systems theory and management", Management Science, Vol. 10 No. 2, pp. 367-384.

Kast, F. E. and Rosenzweig, J. E., (1972), "General systems theory: Applications for organization and management", Academy of Management Journal, Vol. 15 No. 4, pp. 447-465.

Keivanpour, S. and Ait-Kadi, D., (2017), "Modelling end of life phase of the complex products: the case of end of life aircraft", International Journal of Production Research, Vol. 55 No. 12, pp. 3577-3595.

Khan, M., Hussain, M., and Saber, H. M. (2016), "Information sharing in a sustainable supply chain”, International Journal of Production Economics, Vol. 181 No (Part A, November), pp. 208-214.

Kim, M., and Chai, S. (2017), "The impact of supplier innovativeness, information sharing and strategic sourcing on improving supply chain agility: Global supply chain perspective", International Journal of Production Economics, Vol. 187 No. (May), pp. 42-52.

Kock, N. (2014), "Advanced mediating effects tests, multi-group analyses, and measurement model assessments in PLS-based SEM", International Journal of eCollaboration, Vol. 10 No. 1, pp. 1-13.

Kogg, B. and Mont, O., (2012), Environmental and social responsibility in supply chains: The practise of choice and inter-organisational management", Ecological Economics, Vol. 83, pp. 154-163.

Koh, S. C. L., Morris, J., Ebrahimi, S.M., and Obayi. R., (2016), "Integrated resource efficiency: measurement and management", International Journal of Operations \& Production Management, Vol. 36 No. 11, pp. 1576-1600. 
Koh, S. C. L., Gunasekaran, A. and Tseng, C. S., (2012), "Cross-tier ripple and indirect effects of directives WEEE and RoHS on greening a supply chain", International Journal of Production Economics, Vol. 140 No. 1, pp. 305-317.

Kumar, A., Mangla, S. K., Luthra, S. and Ishizaka, A. (2019), "Evaluating the human resource related soft dimensions in green supply chain management implementation", Production Planning \& Control, Vol. 30 No. 9, pp. 699-715.

Kumar, V., Sezersan, I., Garza-Reyes, J. A., Gonzalez, E. D., and AL-Shboul, M. D. A. (2019), "Circular economy in the manufacturing sector: benefits, opportunities and barriers", Management Decision, Vol. 57 No. 4, pp. 1067-1086

Larsen, M. M., Manning, S. and Pedersen, T. (2013), "Uncovering the hidden costs of offshoring: The interplay of complexity, organizational design, and experience", Strategic Management Journal, Vol. 34 No. 5, pp. 533-552.

Lau, G. T, Goh, M., and Phua, S. L., (1999), "Purchase-related factors and buying center structure: An empirical assessment”, Industrial Marketing Management, Vol. 28 No. 6, pp. 573-587.

Lee, J. C. and Chen, C. Y. (2019), "Investigating the environmental antecedents of organizations' intention to adopt agile software development", Journal of Enterprise Information Management, Vol. 32 No. 5, pp. 869-886.

Li, G., Shao, S. and Zhang, L. (2019), "Green supply chain behavior and business performance: Evidence from China", Technological Forecasting and Social Change, Vol. 144 No. (July), pp. 445-455.

Li, Y. and Zhang, M. (2018), "Green manufacturing and environmental productivity growth", Industrial Management \& Data Systems, Vol. 118 No. 6, pp. 1303-1319.

Luthra, S, Garg, D. and Haleem, A., (2015), "Critical success factors of green supply chain management for achieving sustainability in Indian automobile industry", Production Planning \& Control, Vol. 26 No. 5, pp. 339-362.

Luthra, S, Mangla, S. K., Shankar, R., Prakash Garg, C. and Jakhar, S., (2018), "Modelling critical success factors for sustainability initiatives in supply chains in Indian context using Grey-DEMATEL", Production Planning \& Control, Vol. 29 No. 9, pp. 705728.

Lyu, G., Chen, L. and Huo, B. (2019), "Logistics resources, capabilities and operational performance: A contingency and configuration approach”, Industrial Management \& Data Systems, Vol. 119 No. 2, pp. 230-250. 
Malviya, R. K. and Kant, R., (2017), "Modeling the enablers of green supply chain management: An integrated ISM-fuzzy MICMAC approach”, Benchmarking: An International Journal, Vol. 24 No. 2, pp. 536-568.

Mangla, S. K, Luthra, S, Mishra, N., Singh, A., Rana, N. P., Dora, M. and Dwivedi, Y. ., (2018), "Barriers to effective circular supply chain management in a developing country context”, Production Planning \& Control, Vol. 29 No. 6, pp. 551-569.

Mani, V, Gunasekaran, A., Papadopoulos, T., Hazen, B. and Dubey, R., (2016), "Supply chain social sustainability for developing nations: Evidence from India”, Resources, Conservation and Recycling, Vol. 111 No. (August), pp. 42-52.

Marshall, D, McCarthy, L., Heavey, C. and McGrath, P., (2015), "Environmental and social supply chain management sustainability practices: construct development and measurement", Production Planning \& Control, Vol. 26 No. 8, pp. 673-690.

Martinho, J. L., Gomes, C. F. and Yasin, M. M. (2019), "Information technology and the supply chain integration: a business executives' context", International Journal of Business Information Systems, Vol. 30 No. 3, pp. 277-299.

Miemczyk, J, T. Johnsen, E., and Macquet, M., (2012), "Sustainable purchasing and supply management: a structured literature review of definitions and measures at the dyad, chain and network levels", Supply Chain Management: An International Journal, Vol. 17 No. 5, pp. 478-496.

Min, H. (2010), "Artificial intelligence in supply chain management: theory and applications", International Journal of Logistics: Research and Applications, Vol. 13 No. 1, pp. 13-39.

Mishra, D., Gunasekaran, A., Papadopoulos, T. and Childe, S. J. (2018), "Big Data and supply chain management: a review and bibliometric analysis", Annals of Operations Research, Vol. 270 No. (1-2), pp. 313-336.

Namagembe, S., Ryan, S. and Sridharan, R. (2019), "Green supply chain practice adoption and firm performance: manufacturing SMEs in Uganda", Management of Environmental Quality: An International Journal, Vol. 30 No. 1, pp. 5-35.

Narwaria, S. S. (2019), "Conceptual aspect of environment security: evidence from India and Bangladesh", Management of Environmental Quality: An International Journal, Vol. 30 No. 1, pp. 36-46.

Nunnally, J. C. and Bernstein, I. H., (1994), "Psychometric theory (3rd ed.)", New York, NY: McGraw-Hill, Inc 
Oliva, F. L., Semensato, B. I., Prioste, D. B., Winandy, E. J. L., Bution, J. L., Couto, M. H. G. and Singh, S. K. (2019), "Innovation in the main Brazilian business sectors: characteristics, types and comparison of innovation", Journal of Knowledge Management, Vol. 23 No. 1, pp. 135-175.

Omer, A. M. (2008), "Energy, environment and sustainable development", Renewable and Sustainable Energy Reviews, Vol. 12 No. 9, pp. 2265-2300.

Pan, S., Ballot, E., Huang, G. Q., and Montreuil, B. (2017), "Physical Internet and interconnected logistics services: research and applications", International Journal of Production Research, Vol. 55 No. 9, pp. 2603-2609.

Panahifar, F., Byrne, P. J., Salam, M. A. and Heavey, C. (2018), "Supply chain collaboration and firm's performance: the critical role of information sharing and trust”, Journal of Enterprise Information Management, Vol. 31 No. 3, pp. 358-379.

Patnaik, S., Temouri, Y., Tuffour, J., Tarba, S. and Singh, S. K. (2018), "Corporate social responsibility and multinational enterprise identity: insights from a mining company's attempt to localise in Ghana", Social Identities, Vol. 24 No. 5, pp. 604623.

Patten, B. C., (1978), "Systems approach to the concept of environment", The Ohio Journal of Science, Vol. 78 No. 4, pp. 206-222.

Paulraj, A. (2011), "Understanding the relationships between internal resources and capabilities, sustainable supply management and organizational sustainability", Journal of Supply Chain Management, Vol. 47 No. 1, pp. 19-37.

Pettit, T. J., Croxton, K. L. and Fiksel, J. (2019), “The Evolution of Resilience in Supply Chain Management: A Retrospective on Ensuring Supply Chain Resilience”, Journal of Business Logistics. Vol. 40 No. 1, pp.56-65

Peñuelas, J, Sardans, J., Rivas-ubach, A. and Janssens, I. A., (2012), “The human-induced imbalance between C, N and P in Earth's life system" Global Change Biology, Vol. 18 No. 1, pp. 3-6.

Piotrowicz, W. and Cuthbertson, R., (2009), "Sustainability-a new dimension in information systems evaluation", Journal of Enterprise Information Management, Vol. 22 No. 5, pp. 492-503.

Pimentel, D. and Pimentel, M., (2006), "Global environmental resources versus world population growth", Ecological Economics, Vol. 59 No. 2, pp. 195-198. 
Rahman, T., Ali, S. M., Moktadir, M. A. and Kusi-Sarpong, S. (2019), "Evaluating barriers to implementing green supply chain management: An example from an emerging economy", Production Planning \& Control, pp. 1-26.

Rezaei, M., Akbarpour Shirazi, M. and Karimi, B. (2017), "IoT-based framework for performance measurement: a real-time supply chain decision alignment”, Industrial Management \& Data Systems, Vol. 117 No. 4, pp. 688-712.

Ringle, C. M. and Sarstedt, M. (2016), "Gain more insight from your PLS-SEM results: The importance-performance map analysis", Industrial Management \& Data Systems, Vol. 116 No. 9, pp. 1865-1886.

Saberi, S., Cruz, J. M., Sarkis, J. and Nagurney, A. (2018), “A competitive multiperiod supply chain network model with freight carriers and green technology investment option”, European Journal of Operational Research, Vol. 266 No. 3, pp. 934-949.

Saberi, S., Kouhizadeh, M., Sarkis, J. and Shen, L. (2019), "Blockchain technology and its relationships to sustainable supply chain management", International Journal of Production Research, Vol. 57 No. 7, pp. 2117-2135.

Sarkis, J, Zhu, Q. and Lai, K. H. (2011), “An organizational theoretic review of green supply chain management literature", International Journal of Production Economics, Vol. 130 No. 1, pp. 1-15.

Sarkis, J. (2012), "A boundaries and flows perspective of green supply chain management”, Supply Chain Management: An International Journal, Vol. 17 No. 2, pp. 202-216.

Shannon, J. R., (1948), "Percentages of returns of questionnaires in reputable educational research", The Journal of Educational Research, Vol. 42 No. 2, pp. 138-141.

Singh, S. K., Chen, J., Del Giudice, M. and El-Kassar, A. N. (2019), "Environmental ethics, environmental performance, and competitive advantage: Role of environmental training", Technological Forecasting and Social Change, Vol. 146 No. (September), pp. 203-211.

Singh, S. K. and El-Kassar, A. N. (2019), "Role of big data analytics in developing sustainable capabilities", Journal of Cleaner Production, Vol. 213 No. (March), pp. 1264-1273.

Singh, A. S. and Masuku, M. B. (2014), "Sampling techniques \& determination of sample size in applied statistics research: An overview", International Journal of Economics, Commerce and Management, Vol. 2 No. 11, pp. 1-22. 
Singh, A. and Teng, J. T. (2016), "Enhancing supply chain outcomes through Information Technology and Trust”, Computers in Human Behavior, Vol. 54 No. (January), pp. 290-300.

Singh, S. K., Chen, J., Del Giudice, M. and El-Kassar, A. N. (2019a), "Environmental ethics, environmental performance, and competitive advantage: Role of environmental training”, Technological Forecasting and Social Change, Vol. 146 No. (September), pp. 203-211.

Singh, S. K., Mittal, S., Sengupta, A. and Pradhan, R. K. (2019b), “A dual-pathway model of knowledge exchange: linking human and psychosocial capital with prosocial knowledge effectiveness", Journal of Knowledge Management, Vol. 23 No. 5, pp. 889-914.

Singh, S. K., Del Giudice, M., Chierici, R. and Graziano, D. (2020), "Green innovation and environmental performance: The role of green transformational leadership and green human resource management", Technological Forecasting and Social Change, Vol. 150 No. (January), 119762.

Slotnick, S. A. and Sobel, M. J. (2019), "Financial Incentives to Avoid Major Quality Problems in a Supply Chain. Foundations and Trends in Technology, Information and Operations Management, Vol. 12 No. (2-3), pp. 316-333.

Song, M., An, Q., Zhang, W., Wang, Z. and Wu, J. (2012), "Environmental efficiency evaluation based on data envelopment analysis: A review", Renewable and Sustainable Energy Reviews, Vol. 16 No. 7, pp. 4465-4469.

Song, M., Peng, J., Wang, J. and Dong, L. (2018), "Better resource management: An improved resource and environmental efficiency evaluation approach that considers undesirable outputs", Resources, Conservation and Recycling, Vol. 128 No. (January), pp. 197-205.

Song, M. and Wang, S. (2018), "Market competition, green technology progress and comparative advantages in China", Management Decision, Vol. 56 No. 1, pp. 188203.

Song, M., Wang, S. and Cen, L. (2015), "Comprehensive efficiency evaluation of coal enterprises from production and pollution treatment process", Journal of Cleaner Production, Vol. 104 No. (October), pp. 374-379.

Song, M., Wang, S., Yu, H., Yang, L. and Wu, J. (2011), “To reduce energy consumption and to maintain rapid economic growth: Analysis of the condition in China based on 
expended IPAT model”, Renewable and Sustainable Energy Reviews, Vol. 15 No. 9, pp. 5129-5134.

Spina, G., Caniato, F., Luzzini, D., and Ronchi, S., (2016), “Assessing the use of external grand theories in purchasing and supply management research", Journal of Purchasing and Supply Management, Vol. 22 No. 1, pp. 18-30.

Srivastava, S. K., (2007), "Green supply-chain management: a state-of-the-art literature review", International Journal of Management Reviews, Vol. 9 No. 1, pp. 53-80.

Stadtler, H. (2015), "Supply chain management: An overview", In Supply chain management and advanced planning, pp. 3-28. Springer, Berlin, Heidelberg.

Suryanto, T., Haseeb, M. and Hartani, N. H. (2018), “The correlates of developing green supply chain management practices: Firms level analysis in Malaysia", International Journal of Supply Chain Management, Vol. 7 No. 5, pp. 316-324

Tang, D, Wang, Q. and Ullah, I., (2017), "Optimisation of product configuration in consideration of customer satisfaction and low carbon", International Journal of Production Research, Vol. 55 No. 12, pp. 3349-3373.

Themistocleous, M., Roseman, M., Loos, P., de Búrca, S., Fynes, B., \& Marshall, D. (2005). Strategic technology adoption: extending ERP across the supply chain. Journal of Enterprise Information Management. Vol. 18 No. 4, pp. 427-440.

Tseng, M. L., Lim, M., Wu, K. J., Zhou, L. and Bui, D. T. D. (2018), “A novel approach for enhancing green supply chain management using converged interval-valued triangular fuzzy numbers-grey relation analysis", Resources, Conservation and Recycling, Vol. 128 No. (January), pp. 122-133.

Van Aalst, M. K. (2006), "The impacts of climate change on the risk of natural disasters", Disasters, Vol. 30 No. 1, pp. 5-18.

Vanalle, R. M, Ganga, G. M. D., Godinho Filho, M. and Lucato, W. C. (2017), "Green supply chain management: An investigation of pressures, practices, and performance within the Brazilian automotive supply chain", Journal of Cleaner Production, Vol. 151 No. (May), pp. 250-259.

Waltho, C., Elhedhli, S. and Gzara, F. (2018), "Green supply chain network design: A review focused on policy adoption and emission quantification", International Journal of Production Economics. Vol. 208 No. (February), pp. 305-318

Wang, F., Lai, X., and Shi, N., (2011), “A multi-objective optimization for green supply chain network design”, Decision Support Systems, Vol. 51 No. 2, pp. 262-269. 
Ware, N. R, Singh, S. P. and Banwet, D. K., (2014), "Modeling flexible supplier selection framework", Global Journal of Flexible Systems Management, Vol. 15 No. 3, pp.261-274.

Wu, L., Chuang, C. H., and Hsu, C. H. (2014), "Information sharing and collaborative behaviors in enabling supply chain performance: A social exchange perspective", International Journal of Production Economics, Vol. 148 No. (February), pp. 122-132.

Xu, X., He, P., Xu, H. and Zhang, Q. (2017), "Supply chain coordination with green technology under cap-and-trade regulation", International Journal of Production Economics, Vol. 183 No. (Part B, January), pp. 433-442.

Yeniyurt, S., Wu, F., Kim, D. and Cavusgil, S. T. (2019), "Information technology resources, innovativeness, and supply chain capabilities as drivers of business performance: A retrospective and future research directions", Industrial Marketing Management, Vol. 79 No. (May), pp. 46-52.

Zhang, H., and Yang, F. (2016), "On the drivers and performance outcomes of green practices adoption: an empirical study in China”, Industrial Management \& Data Systems, Vol. 116 No. 9, pp. 2011-2034.

Zhu, Q, Sarkis, J. and Geng, Y. (2005), “Green supply chain management in China: pressure, practices and performance", International Journal of Operations and Production Management, Vol. 25 No. 5, pp. 449-468.

Zhu, Q., Qu, Y., Geng, Y. and Fujita, T. (2017), “A comparison of regulatory awareness and green supply chain management practices among Chinese and Japanese manufacturers", Business Strategy and the Environment, Vol. 26 No. 1, pp. 18-30.

Zimmer, K, Fröhling, M. and Schultmann, F., (2016), "Sustainable supplier management-a review of models supporting sustainable supplier selection, monitoring and development”, International Journal of Production Research, Vol. 54 No. 5, pp. $1412-1442$ 
Table 1. Demographic profile of respondents

\begin{tabular}{|c|c|c|c|}
\hline Particulars & Respondents & $\mathrm{N}$ & $\%$ \\
\hline \multirow{5}{*}{ Designation } & Managing Director & 12 & 4.80 \\
\hline & Senior Manager & 95 & 38.00 \\
\hline & Manager & 63 & 25.20 \\
\hline & Deputy Manager & 54 & 21.60 \\
\hline & Assistant Manager & 26 & 10.40 \\
\hline \multirow{7}{*}{$\begin{array}{l}\text { Job Experience } \\
\text { (Years) }\end{array}$} & Above 25 & 12 & 4.80 \\
\hline & $16-25$ & 110 & 44.00 \\
\hline & 10 to 15 & 69 & 27.60 \\
\hline & 6 to 9 & 37 & 14.80 \\
\hline & $0-5$ & 22 & 8.80 \\
\hline & $\begin{array}{l}\text { Automobile } \\
\text { manufacturers }\end{array}$ & 35 & 14.00 \\
\hline & $\begin{array}{l}\text { Automotive component } \\
\text { and allied manufacturers }\end{array}$ & 215 & 86.00 \\
\hline \multirow{5}{*}{$\begin{array}{c}\text { Age of the Organization } \\
\text { (Years) }\end{array}$} & $>20$ & 85 & 34.00 \\
\hline & 15 to 20 & 110 & 44.00 \\
\hline & 10 to 14 & 37 & 14.80 \\
\hline & 5 to 9 & 18 & 7.20 \\
\hline & 1 to 4 & 0 & 0.00 \\
\hline \multirow{3}{*}{$\begin{array}{c}\text { Annual Revenue } \\
\text { (South African Rands) }\end{array}$} & $\begin{array}{c}<\mathrm{R} 10 \text { million } \\
\text { (Exempted Micro } \\
\text { Enterprise) }\end{array}$ & 12 & 4.80 \\
\hline & $\begin{array}{c}<\mathrm{R} 50 \text { million } \\
\text { (Qualifying Small } \\
\text { Enterprise) }\end{array}$ & 70 & 28.00 \\
\hline & $>$ R50 million (Generic) & 168 & 67.20 \\
\hline \multirow{4}{*}{$\begin{array}{l}\text { Number of employees in } \\
\text { the Organization }\end{array}$} & $<500$ & 94 & 37.60 \\
\hline & 250 to 500 & 118 & 47.20 \\
\hline & $101-249$ & 30 & 12.00 \\
\hline & $>100$ & 8 & 3.20 \\
\hline
\end{tabular}


Table 2. Latent variable coefficients

\begin{tabular}{|c|c|c|c|c|c|c|c|c|c|c|}
\hline $\begin{array}{c}\text { Latent variable } \\
\text { coefficients }\end{array}$ & $\begin{array}{c}\text { GSCM } \\
\text { HD }\end{array}$ & GSCMS & $\begin{array}{c}\text { GSCM } \\
\text { PR }\end{array}$ & EP & SP & FP & PC & PS & $\begin{array}{c}\text { PC*GS } \\
\text { CM }\end{array}$ & $\begin{array}{c}\text { PS*GSC } \\
\text { M }\end{array}$ \\
\hline R-squared coefficients & & 0.642 & 0.788 & 0.132 & 0.278 & 0.136 & & & & \\
\hline $\begin{array}{c}\text { Adjusted R-squared } \\
\text { coefficients }\end{array}$ & & 0.639 & 0.786 & 0.129 & 0.275 & 0.133 & & & & \\
\hline $\begin{array}{c}\text { Composite reliability } \\
\text { coefficients }\end{array}$ & 0.854 & 0.782 & 0.926 & 0.973 & 0.972 & 0.823 & 0.960 & 0.934 & 0.950 & 0.942 \\
\hline $\begin{array}{c}\text { Cronbach's alpha } \\
\text { coefficients }\end{array}$ & 0.802 & 0.712 & 0.905 & 0.965 & 0.957 & 0.678 & 0.947 & 0.905 & 0.938 & 0.938 \\
\hline $\begin{array}{c}\text { Average variances } \\
\text { extracted }\end{array}$ & 0.401 & 0.360 & 0.615 & 0.877 & 0.922 & 0.608 & 0.827 & 0.781 & 0.397 & 0.417 \\
\hline Full collinearity VIFs & 2.571 & 4.880 & 4.688 & 2.726 & 2.726 & 2.854 & 10.334 & 1.923 & 11.648 & 2.462 \\
\hline Q-squared coefficients & & 0.530 & 0.739 & 0.148 & 0.270 & 0.137 & & & & \\
\hline
\end{tabular}

Table 3. Results of Hypotheses Testing

\begin{tabular}{|c|c|c|c|c|}
\hline No. & Research Hypotheses & Beta Value & p-value & $\begin{array}{c}\text { Research } \\
\text { Hypotheses } \\
\text { supported/not } \\
\text { supported }\end{array}$ \\
\hline H1 & GSCM HD positively influences GSCMS & 0.12 & 0.03 & Supported \\
\hline H2 & GSCMS positively influences GSCMP & 0.39 & $<.01$ & Supported \\
\hline H3a & GSCM PR positively influences EP & 0.36 & $<.01$ & Supported \\
\hline H3b & GSCM PR positively influences SP & 0.53 & $<.01$ & Supported \\
\hline H3c & GSCM PR positively influences FP & 0.37 & $<.01$ & Supported \\
\hline H4 & $\begin{array}{c}\text { PC has moderation effect on GSCMS impact on } \\
\text { GSCM PR }\end{array}$ & $(-0.52)$ & $<.01$ & Supported \\
\hline H5 & $\begin{array}{c}\text { PS has moderation effect on GSCMS impact on } \\
\text { GSCM PR }\end{array}$ & $(-0.05)$ & 0.20 & $\begin{array}{c}\text { Not } \\
\text { supported }\end{array}$ \\
\hline
\end{tabular}


Table 4. Constructs and Measures

\begin{tabular}{|c|c|c|}
\hline Constructs & Measures & Adapted from \\
\hline \multirow{10}{*}{$\begin{array}{l}\text { GSCM (AI-based } \\
\text { Technological } \\
\text { Dimensions) } \\
\text { (GSCM HD) }\end{array}$} & $\begin{array}{l}\text { We use Agent based systems for green } \\
\text { demand planning and forecasting }\end{array}$ & \multirow{10}{*}{$\operatorname{Min}(2010)$} \\
\hline & $\begin{array}{l}\text { We use Agent based systems for } \\
\text { negotiation with green suppliers }\end{array}$ & \\
\hline & $\begin{array}{l}\text { We use Agent based systems for green } \\
\text { customer relationship management }\end{array}$ & \\
\hline & $\begin{array}{l}\text { We use Agent based systems for order } \\
\text { picking in green warehouse management }\end{array}$ & \\
\hline & $\begin{array}{l}\text { We use Agent based systems for } \\
\text { integration and coordination in green } \\
\text { supply chain }\end{array}$ & \\
\hline & $\begin{array}{l}\text { We use Genetic algorithm for green } \\
\text { supply chain network design }\end{array}$ & \\
\hline & $\begin{array}{l}\text { We use Expert systems for green logistics } \\
\text { strategy formulation }\end{array}$ & \\
\hline & $\begin{array}{l}\text { We use Expert systems for green } \\
\text { inventory planning and management }\end{array}$ & \\
\hline & $\begin{array}{l}\text { We use Expert systems for green decision } \\
\text { making (manufacture in-house or buying } \\
\text { from outside source) }\end{array}$ & \\
\hline & $\begin{array}{l}\text { We use Expert systems for green supplier } \\
\text { selection }\end{array}$ & \\
\hline
\end{tabular}


Table 4. Constructs and Measures... continued

\begin{tabular}{|c|c|c|}
\hline Constructs & Measures & Source \\
\hline \multirow{10}{*}{$\begin{array}{l}\text { GSCM Strategy } \\
\text { (GSCMS) }\end{array}$} & $\begin{array}{l}\text { Firm focuses on single sourcing } \\
\text { for specialised components }\end{array}$ & \multirow{10}{*}{ Dubey et al. (2017) } \\
\hline & $\begin{array}{l}\text { Supply base reduction is } \\
\text { important for managing annual } \\
\text { rate contracts }\end{array}$ & \\
\hline & $\begin{array}{l}\text { Green supplier development and } \\
\text { periodic evaluation minimize } \\
\text { supply risks }\end{array}$ & \\
\hline & $\begin{array}{c}\text { Firm focus on cost management } \\
\text { through reducing costs and } \\
\text { wastages } \\
\end{array}$ & \\
\hline & $\begin{array}{l}\text { Firm strives to improve efficiency } \\
\text { and increase asset utilization }\end{array}$ & \\
\hline & $\begin{array}{l}\text { Firm intends to reduce total cost } \\
\text { of ownership }\end{array}$ & \\
\hline & $\begin{array}{c}\text { Firm enhances supplier R\&D } \\
\text { capabilities }\end{array}$ & \\
\hline & $\begin{array}{c}\text { Firm focus on developing } \\
\text { flexibility in manufacturing } \\
\text { systems } \\
\end{array}$ & \\
\hline & $\begin{array}{l}\text { Firm has improved success rate } \\
\text { for launching new green products } \\
\text { and services }\end{array}$ & \\
\hline & $\begin{array}{l}\text { Firm has developed specialized } \\
\text { knowledge and technology for } \\
\text { implementing closed loop } \\
\text { strategy }\end{array}$ & \\
\hline \multirow{2}{*}{$\begin{array}{c}\text { Purchasing Structure } \\
\text { (PS) }\end{array}$} & $\begin{array}{c}\text { Green procurement is executed } \\
\text { locally with corporate } \\
\text { involvement }\end{array}$ & \multirow{2}{*}{ Ates et al. (2018) } \\
\hline & $\begin{array}{l}\text { Corporate provides mandatory } \\
\text { templates for local green } \\
\text { procurement execution }\end{array}$ & \\
\hline
\end{tabular}


Green procurement process is guided by internal policy and measures

Cross-functionality decision making is considered in the green procurement processes

Table 4. Constructs and Measures... continued

\begin{tabular}{|c|c|c|}
\hline Constructs & Measures & Source \\
\hline \multirow{5}{*}{$\begin{array}{l}\text { Product Complexity } \\
\text { (PC) }\end{array}$} & $\begin{array}{l}\text { Product and technology portfolio } \\
\text { involves complex decisions }\end{array}$ & \multirow{5}{*}{ Eckstein et al. (2015) } \\
\hline & $\begin{array}{l}\text { There is high scale of } \\
\text { customization of green products } \\
\text { and components }\end{array}$ & \\
\hline & $\begin{array}{l}\text { Complexity and selection of } \\
\text { system framework is performed } \\
\text { based on decision support } \\
\text { systems }\end{array}$ & \\
\hline & $\begin{array}{l}\text { The intensity of user involvement } \\
\text { is high in complex product } \\
\text { designs }\end{array}$ & \\
\hline & $\begin{array}{l}\text { The intensity of supplier } \\
\text { involvement is high in complex } \\
\text { product designs }\end{array}$ & \\
\hline \multirow{5}{*}{ GSCM Process (PR) } & $\begin{array}{l}\text { The designed process is capable } \\
\text { to adjust to the changes in } \\
\text { customer demands }\end{array}$ & \multirow{5}{*}{ Dubey et al. (2017) } \\
\hline & $\begin{array}{c}\text { Firm focus on proactive } \\
\text { innovation by raising the green } \\
\text { management capabilities and then } \\
\text { integrating with the business } \\
\text { strategy }\end{array}$ & \\
\hline & $\begin{array}{c}\text { Firm focus on increased } \\
\text { innovations for enhancing green } \\
\text { management performance }\end{array}$ & \\
\hline & $\begin{array}{c}\text { Firm focus on active integration } \\
\text { by developing collaborative } \\
\text { relations with suppliers and } \\
\text { customers } \\
\end{array}$ & \\
\hline & $\begin{array}{l}\text { Firm integrate green programs } \\
\text { with other business functions }\end{array}$ & \\
\hline
\end{tabular}


Firm consider the benchmarking practices in world class

organizations and continuously improve its capabilities

Firm conforms with ecological regulations

Firm obey customers'

environmental instructions

Table 4. Constructs and Measures... continued

\begin{tabular}{|c|c|c|}
\hline Constructs & Measures & Source \\
\hline \multirow{5}{*}{$\begin{array}{c}\text { Environmental } \\
\text { Performance (EP) }\end{array}$} & $\begin{array}{c}\text { Firm annually saves significant } \\
\text { costs from GSCM }\end{array}$ & \multirow{5}{*}{$\begin{array}{c}\text { Jabbour et al. (2015); Dubey } \\
\text { et al. (2016) }\end{array}$} \\
\hline & $\begin{array}{l}\text { Firm annually saves significant } \\
\text { natural resources from GSCM }\end{array}$ & \\
\hline & $\begin{array}{c}\text { Reduced maintenance and } \\
\text { downtime of plant machineries } \\
\text { after GSCM implementation }\end{array}$ & \\
\hline & $\begin{array}{l}\text { Extended life of final products } \\
\text { due to special material used }\end{array}$ & \\
\hline & $\begin{array}{l}\text { Easy to handle, install and } \\
\text { operate the final green product }\end{array}$ & \\
\hline \multirow{3}{*}{ Social Performance (SP) } & $\begin{array}{l}\text { Improved occupational health and } \\
\text { safety of plant workers }\end{array}$ & \multirow{3}{*}{$\begin{array}{c}\text { Jabbour et al. (2015); Dubey } \\
\text { et al. (2016) }\end{array}$} \\
\hline & $\begin{array}{l}\text { GSCM strictly eliminated any } \\
\text { child labour in factory operations }\end{array}$ & \\
\hline & $\begin{array}{l}\text { GSCM improved focus on } \\
\text { customer health and safety }\end{array}$ & \\
\hline \multirow{3}{*}{$\begin{array}{l}\text { Financial Performance } \\
\qquad(\mathrm{FP})\end{array}$} & $\begin{array}{l}\text { Enhanced profitability by } \\
\text { reducing costs of goods sold }\end{array}$ & \multirow{3}{*}{$\begin{array}{c}\text { Jabbour et al. (2015); Dubey } \\
\text { et al. (2016) }\end{array}$} \\
\hline & Increase in market share & \\
\hline & Enhanced customer retention & \\
\hline
\end{tabular}

Table 5. Correlations among latent variables with square roots of AVEs shown on diagonal

\begin{tabular}{|l|l|l|l|l|l|l|l|l|l|l|}
\hline & GSCM HD & GSCMS & GSCM PR & EP & SP & FP & PC & PS & PC*GSCM & PS*GSCM \\
\hline GSCM HD & $\mathbf{0 . 6 3 3}$ & 0.442 & 0.443 & 0.573 & 0.454 & 0.459 & 0.417 & 0.510 & -0.349 & -0.383 \\
\hline GSCMS & 0.442 & $\mathbf{0 . 6 0 0}$ & 0.808 & 0.451 & 0.237 & 0.229 & 0.852 & 0.303 & -0.826 & -0.422 \\
\hline GSCM PR & 0.443 & 0.808 & $\mathbf{0 . 7 8 4}$ & 0.351 & 0.371 & 0.284 & 0.805 & 0.295 & -0.766 & -0.403 \\
\hline EP & 0.573 & 0.451 & 0.351 & $\mathbf{0 . 9 3 7}$ & 0.396 & 0.599 & 0.410 & 0.625 & -0.438 & -0.415 \\
\hline SP & 0.454 & 0.237 & 0.371 & 0.396 & $\mathbf{0 . 9 6 0}$ & 0.722 & 0.234 & 0.288 & -0.230 & -0.419 \\
\hline FP & 0.459 & 0.229 & 0.284 & 0.599 & 0.722 & $\mathbf{0 . 7 8 0}$ & 0.203 & 0.425 & -0.215 & -0.360 \\
\hline
\end{tabular}




\begin{tabular}{|l|l|l|l|l|l|l|l|l|l|l|}
$\mathrm{PC}$ & 0.417 & 0.852 & 0.805 & 0.410 & 0.234 & 0.203 & $\mathbf{0 . 9 0 9}$ & 0.322 & -0.922 & -0.457 \\
\hline $\mathrm{PS}$ & 0.510 & 0.303 & 0.295 & 0.625 & 0.288 & 0.425 & 0.322 & $\mathbf{0 . 8 8 4}$ & -0.334 & -0.454 \\
\hline $\mathrm{PC} * \mathrm{GSCM}$ & -0.349 & -0.826 & -0.766 & -0.438 & -0.230 & -0.215 & -0.922 & -0.334 & $\mathbf{0 . 6 3 0}$ & 0.603 \\
\hline PS*GSCM & -0.383 & -0.422 & -0.403 & -0.415 & -0.419 & -0.360 & -0.457 & -0.454 & 0.603 & $\mathbf{0 . 6 4 6}$ \\
\hline
\end{tabular}

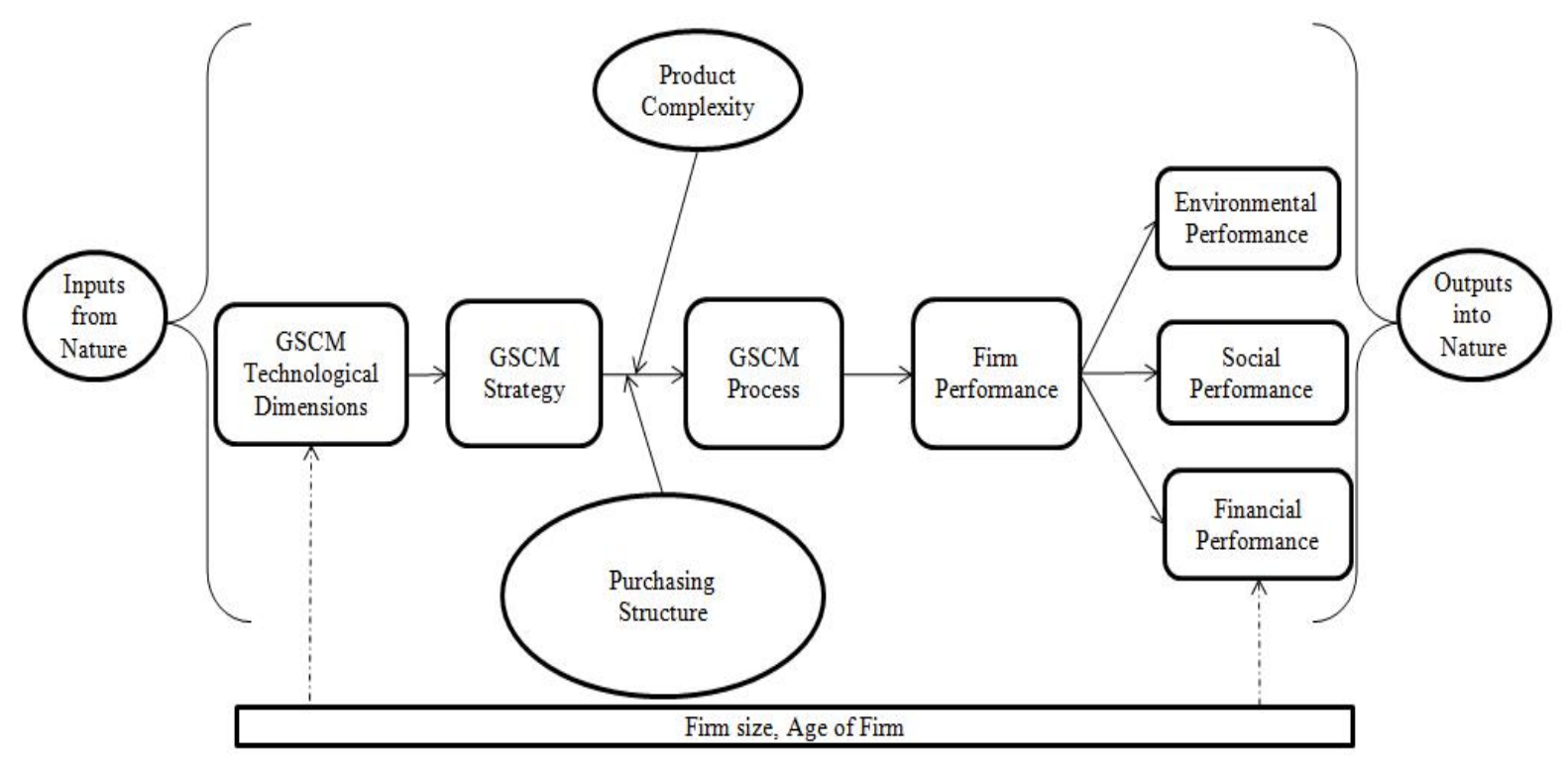

Figure 1. Conceptual framework of GSCM 


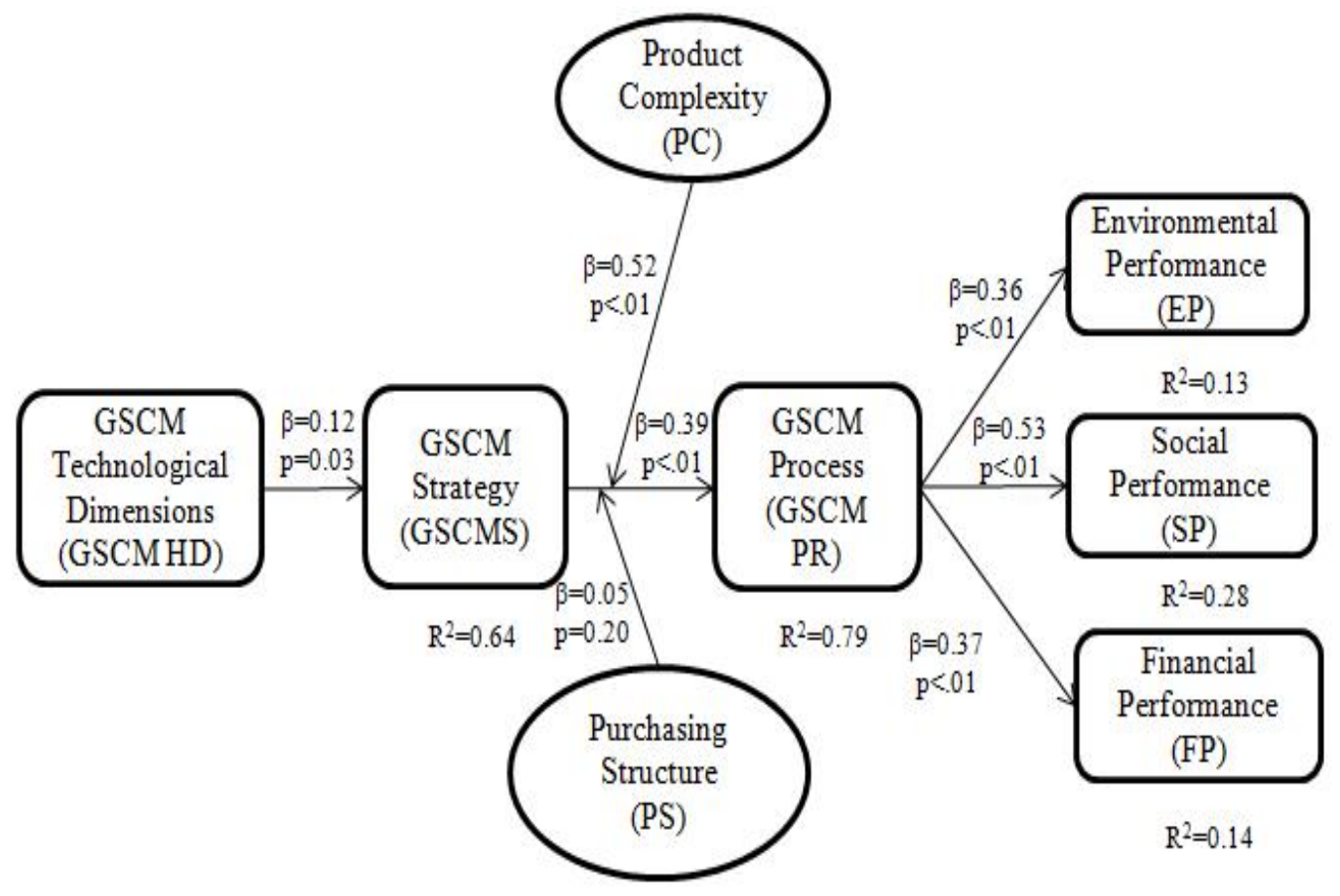

Figure 2. Tested GSCM model 